\title{
Dominant Height Growth in Tectona grandis Plantations in Mato Grosso, Brazil
}

\author{
Diogo Guido Streck Vendruscolo ${ }^{1}$ (i), Ronaldo Drescher $^{1}$ (i), \\ Samuel de Pádua Chaves e Carvalho ${ }^{1}$ (D), Reginaldo Antonio Medeiros ${ }^{2}$ (D), \\ Rômulo Môra ${ }^{1}$ (D), Alvaro Augusto Vieira Soares ${ }^{3}$ \\ ${ }^{1}$ Universidade Federal de Mato Grosso (UFMT), Cuiabá, MT, Brasil \\ ${ }^{2}$ Instituto Federal de Educação Ciência e Tecnologia de Mato Grosso (IFMT), Cáceres, MT, Brasil \\ ${ }^{3}$ Universidade Federal de Uberlândia (UFU), Monte Carmelo, MG, Brasil
}

\begin{abstract}
Tectona grandis (teak) plantations have gained increased interest in recent decades in Brazil, bringing about the need for acquiring information regarding the growth and productive potential. The present work aims to evaluate the growth of dominant height in teak at various locations in the state of Mato Grosso, midwest Brazil. For this purpose, six stands were evaluated in distinct municipalities and the database was obtained from trunk analysis. Subsequently, the dominant height growth was estimated using nonlinear regression models, whose performance was evaluated, based on goodness-of-fit statistics and graphical analysis of residues. Tests for model identity were used to analyze the differences in growth rates between sites (municipalities). The studied teak stands displayed different dominant height growth trends, with differences reaching up to $37 \%$.
\end{abstract}

Keywords: teak, forest management, growth models, test for model identity. 


\section{INTRODUCTION AND OBJECTIVES}

Teak (Tectona grandis L.f) stands out among the tropical timber species due to its aesthetic, physical, and workability properties, among other characteristics that give it a high value in the international market (Kollert \& Cherubini, 2012). Predominantly the teak wood is utilized for building ships and manufacturing luxury furniture. Apart from this, there also exists a possibility of commercialization of timber extracted in the first thinning, which is either used for energy or for the manufacture of less valuable furniture (Cunha Neto et al., 2016; Pandey \& Brown, 2000; Pelissari et al., 2014).

Plantations of this species in Brazil have been established, mainly in the states of Pará, Rondônia, Acre and Mato Grosso, which is currently the largest planted area, corresponding to $78 \%$ of a total of 87.4 thousand hectares (IBÁ, 2016). Although there is an increasing trend of expansion of areas planted with teak, Brazilian experience is still incipient when compared to Eucalyptus and Pinus.

Some researches indicate that the areas cultivated with teak have contrasting environmental characteristics that result in different rates of growth and productive capacity. For example, Shimizu et al. (2007) showed that these differences in productive capacity and growth characteristics exist among different regions in the state of Mato Grosso. Corroborating this finding, Medeiros et al. (2018) showed that productivity differences across the state of Mato Grosso are due to climatic, physiographic, and especially, edaphic factors, which are the most restrictive cause of teak cultivation in this state. Therefore, efforts to characterize the growth and productive capacity of teak stands are essential for supporting silvicultural treatments and also for assisting management decision making in order to consolidate this culture in the national sector, thereby raising its production to competitive levels in the international scenario.

A widely used metric for the characterization of the productive capacity of forest stands is the site index, defined by the mean height of the dominant trees at a reference age (Burkhart \& Tomé, 2012; Campos \& Leite, 2013). Modeling the dominant height along stand age is an effective way of characterizing and quantifying tree growth. It is the advantage of allowing the comparison of the growth between plantations with different densities and under different management regimes (for example, thinned versus non-thinned stands), since spacing and thinning from below have little impact on this variable (Campos \& Leite, 2013; Prodan et al., 1997).

Given the prominent importance of teak to the Brazilian forestry sector and the need to characterize the differences in growth and productive capacity of this species to promote an efficient and competitive management, this work aimed to describe the growth of dominant height of Tectona grandis stands, in different regions of the state of Mato Grosso (MT), Midwest Brazil.

\section{MATERIALS AND METHODS}

\subsection{Study regions and data}

The present work was carried out with data from commercial and experimental teak stands originated from seedling plantation in six municipalities located in different regions of the state of MT, mid-west Brazil (Figure 1): Alta Floresta, in the northern region; Nova Maringá in the mid-north region; Santo Antônio do Leverger and Cáceres in the mid-south region; Indiavai and Figueirópolis d'Oeste in the western region.

The database used in this study was obtained from dominant trees, whose growth was reconstituted by complete stem analysis. For the selection of the dominant trees, a forest census was first carried out in the experimental areas (Figueirópolis d'Oeste and Cáceres), followed by DBH (diameter at $1.30 \mathrm{~m}$ height) measurements in some permanent and temporary plots installed in commercial plantations (Alta Floresta, Nova Maringá, Indiavaí, and Santo Antônio do Leverger). The plot area ranged from $900 \mathrm{~m}^{2}$ to $1,600 \mathrm{~m}^{2}$, depending on the site, where for every $100 \mathrm{~m}^{2}$ one dominant tree was identified (Assmann, 1970). The main characteristics of the areas and the number of dominant trees felled in the studied stands are shown in Table 1. In the Caceres stand, planted at different spacings, the same number of dominant trees was sampled for each planting density.

Discs at the following heights $-0.10 \mathrm{~m}$ (base); $1.30 \mathrm{~m}(\mathrm{DBH})$; and every $2 \mathrm{~m}$ from the $\mathrm{DBH}$ on the commercial stem and, then, at every $1 \mathrm{~m}$ up to the diameter of $5 \mathrm{~cm}$ - were collected for complete stem analysis. Further, to facilitate the visualization of the annual growth rings, the surface of the discs was sanded, an essential step to avoid the marking of 


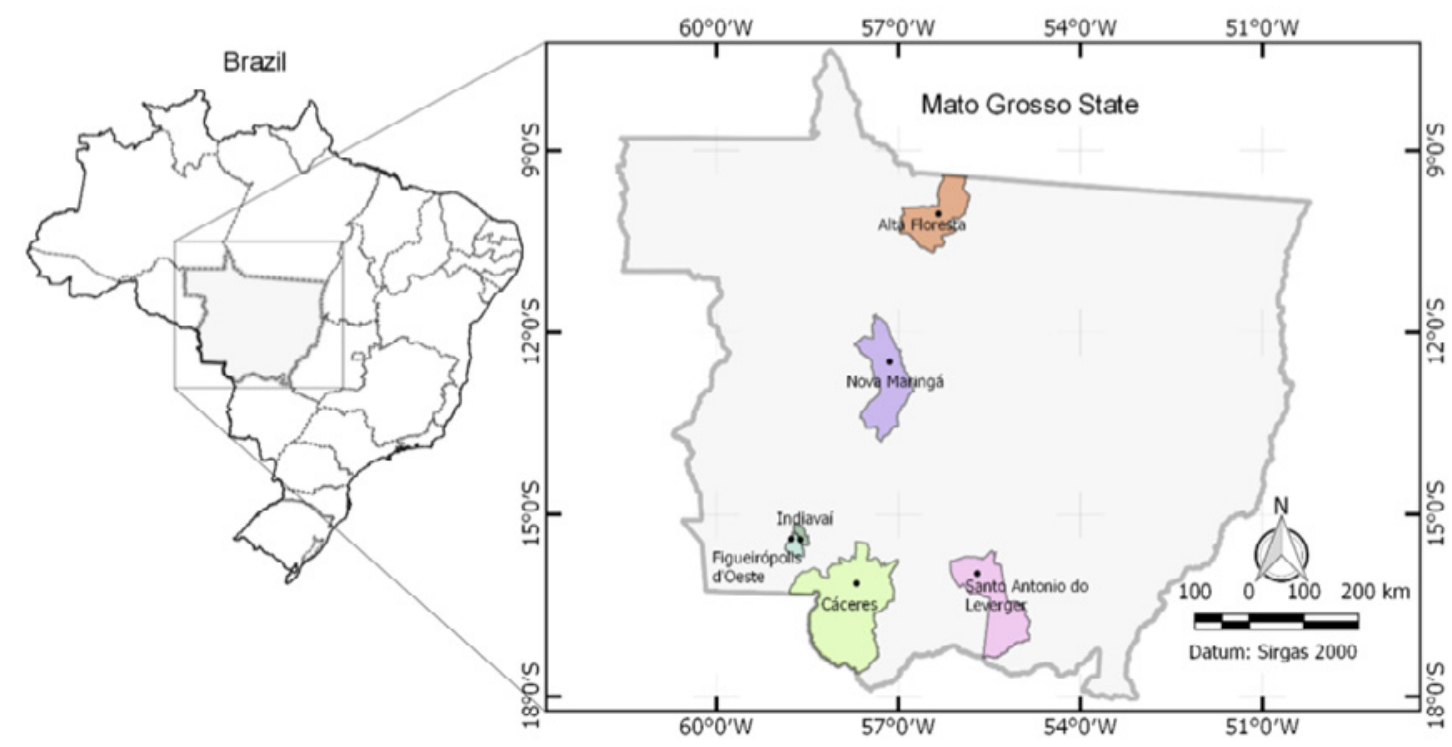

Figure 1. Location of the studied Tectona grandis stands, in the state of Mato Grosso, mid-west Brazil.

Table 1. Main characteristics of the studied Tectona grandis stands.

\begin{tabular}{|c|c|c|c|c|c|c|c|c|}
\hline Site & Age & $\mathbf{T}$ & $\mathbf{P}$ & Alt & Sp & Silv. Treatments & Thinning & TA \\
\hline Cáceres & 17 & $24-26$ & $1,600-1,900$ & 118 & $\begin{array}{l}3 \times 24 \times 2 \\
5 \times 2 \quad 6 \times 2\end{array}$ & $\begin{array}{l}\text { Pruning at the ages of } 9 \text {, } \\
14 \text { e } 22 \text { months }\end{array}$ & No thinning & 16 \\
\hline Indiavaí & 33 & $24-26$ & $1,600-1,900$ & 185 & $2 \times 2$ & $\begin{array}{l}\text { Periodic pruning to } \\
\text { keep the stem free of } \\
\text { branches }\end{array}$ & $\begin{array}{l}\text { At the ages of } 6, \\
11,14,20,23 \text { and } \\
26\end{array}$ & 12 \\
\hline $\begin{array}{l}\text { Figueirópolis } \\
\text { d'Oeste }\end{array}$ & 6 & $24-26$ & $1,600-1,900$ & 370 & $4 \times 2$ & Semestral pruning & No thinning & 12 \\
\hline $\begin{array}{l}\text { Nova } \\
\text { Maringá }\end{array}$ & 16 & $24-26$ & $1,900-2,200$ & 375 & $3 \times 3$ & $\begin{array}{l}\text { Fertilization in the } 1 \text { st } \\
\text { e } 2 \text { nd year (NPK) and } \\
\text { yearly prunings }\end{array}$ & $\begin{array}{l}\text { At the ages of } 5 \text {, } \\
\qquad 8 \text { e } 12\end{array}$ & 10 \\
\hline $\begin{array}{l}\text { Santo } \\
\text { Antônio do } \\
\text { Leverger }\end{array}$ & 9 & $24-26$ & $1,300-1,600$ & 140 & $3 \times 2$ & Periodic pruning & No thinning & 9 \\
\hline Alta Floresta & 10 & $26-28$ & $2,800-3,100$ & 300 & $3 \times 2$ & $\begin{array}{l}\text { Periodic prunings } \\
\text { and the elimination of } \\
\text { defectitve trees }\end{array}$ & At the age of 6 & 10 \\
\hline
\end{tabular}

Age: stand age (years); T: mean annual temperature $\left({ }^{\circ} \mathrm{C}\right)$; P: mean annual precipitation (mm); Alt: altitude (m); Sp: planting spacing $(\mathrm{m} \times \mathrm{m})$; TA: number of trees sampled for the complete trunk analysis.

false rings, which are common in teak, as observed by Priya \& Bhat (1998). A traditional methodology, which consists of tracing four rays in the discs, was used for the complete stem analysis. The width of the rings was measured using a millimeter ruler. The mean of the four radii measured on each disc ring was assumed to be the radius representative of that ring, as stated by Chaves et al. (2016), Drescher et al. (2016) and Machado et al. (2010).
After discs measurements and data grouping, the radii were plotted against heights of the trunk obtained at the various ages of each tree. The height growth of the trees was reconstructed, according to the procedure detailed by Campos \& Leite (2013). A summary of the descriptive statistics of the variables such as diameter at $1.30 \mathrm{~m}$ height $(\mathrm{DBH})$ and dominant height (DH) of the sampled trees is presented in Table 2. 


\subsection{Dominant height modeling}

To describe the growth of dominant height in teak trees at different sites, four non-linear regression models (Models 1 to 4), fitted by the stand, were tested. The estimation of regression parameters was carried out using the Gauss-Newton algorithm, as shown in Equations 1 to 4 .

\section{Gompertz}

$\mathrm{DH}_{\mathrm{ij}}=\beta_{0}\left[\exp ^{-\exp ^{\beta_{1}-\beta_{2} \cdot A g \mathrm{ge}_{i}}}\right]+\varepsilon_{\mathrm{ij}}$

Chapman-Richards

$\mathrm{DH}_{\mathrm{ij}}=\beta_{0}\left[1-\exp ^{-\exp ^{-\beta_{1} \cdot A \mathrm{gei}_{\mathrm{i}}}}\right]^{\beta_{2}}+\varepsilon_{\mathrm{ij}}$

Weibull

$$
\mathrm{DH}_{\mathrm{ij}}=\beta_{0}\left[1-\exp ^{-\beta_{1} \cdot \mathrm{Age}_{\mathrm{i}}^{\beta_{2}}}\right]+\varepsilon_{\mathrm{ij}}
$$

Schumacher

$$
\mathrm{DH}_{\mathrm{ij}}=\exp \left(\beta_{0}+\beta_{1} \cdot \frac{1}{\mathrm{Age}_{\mathrm{i}}}\right)+\varepsilon_{\mathrm{ij}}
$$

$D H_{i:}$ : dominant height of the $i$-th tree in the $j$-th age $(\mathrm{m}) ; \beta_{i}$ : model coefficients; exp: exponential; Age: age of the $i$-th tree (years); $\varepsilon_{i j}$ : random error of the $i$-th tree in the $j$-th age.

\begin{tabular}{|c|c|c|c|c|c|c|}
\hline Site & Age & Variable & $\overline{\mathbf{X}}$ & $\mathbf{S}$ & Min & Max \\
\hline \multirow{2}{*}{ Cáceres } & \multirow{2}{*}{17} & $\mathrm{DBH}$ & 21.7 & 2.1 & 18.0 & 25.0 \\
\hline & & $\mathrm{DH}$ & 19.7 & 0.9 & 17.9 & 21.1 \\
\hline \multirow{2}{*}{ Indiavaí } & \multirow{2}{*}{33} & $\mathrm{DBH}$ & 44.2 & 5.4 & 31.4 & 52.0 \\
\hline & & DH & 25.3 & 1.4 & 21.9 & 27.0 \\
\hline \multirow{2}{*}{$\begin{array}{l}\text { Figueirópolis } \\
\text { d'Oeste }\end{array}$} & \multirow{2}{*}{6} & $\mathrm{DBH}$ & 11.3 & 0.9 & 10.1 & 13.1 \\
\hline & & DH & 11.8 & 0.4 & 11.1 & 12.6 \\
\hline \multirow{2}{*}{$\begin{array}{l}\text { Nova } \\
\text { Maringá }\end{array}$} & \multirow{2}{*}{16} & $\mathrm{DBH}$ & 29.7 & 2.6 & 26.5 & 34.8 \\
\hline & & DH & 20.6 & 1.3 & 18.9 & 22.5 \\
\hline \multirow{2}{*}{$\begin{array}{l}\text { Santo } \\
\text { Antônio do } \\
\text { Leverger }\end{array}$} & \multirow{2}{*}{9} & $\mathrm{DBH}$ & 15.2 & 4.7 & 10.8 & 21.6 \\
\hline & & DH & 14.1 & 3.1 & 10.9 & 18.6 \\
\hline \multirow{2}{*}{ Alta Floresta } & \multirow{2}{*}{10} & $\mathrm{DBH}$ & 17.4 & 1.8 & 14.6 & 20.2 \\
\hline & & $\mathrm{DH}$ & 16.7 & 1.4 & 13.9 & 19.1 \\
\hline
\end{tabular}

Table 2. Statistical summary of dominant trees sampled.

Age: stand age (years); $\overline{\mathrm{X}}$ : mean; S: standard deviation; Min: minimum; Max: maximum; DBH: diameter at $1,30 \mathrm{~m}$ above ground $(\mathrm{cm})$; DH: dominant height $(\mathrm{m})$.
Goodness-of-fit and precision of the models were evaluated with the following statistics: higher correlation coefficient (, Equation 5); lower root mean square error in percentage (RMSE\%, Equation 6); significant regression coefficients $(\beta)$ by Student's $t$ test at 5\% significance; and no evidence of departures from normality and homoscedasticity in the graphic analysis of the residues (Equation 7). The chosen model was the one that presented the best performance in most of the six locations.

$r_{y \hat{y}}=\frac{\operatorname{cov}(y, \hat{y})}{\sqrt{S^{2}(y) S^{2}(\hat{y})}}$

$\operatorname{RMSE} \%=\frac{100}{\bar{y}} \sqrt{\frac{\sum_{\mathrm{i}=1}^{\mathrm{n}}\left(\mathrm{y}_{\mathrm{i}}-\hat{\mathrm{y}}_{\mathrm{i}}\right)^{2}}{\mathrm{n}}}$

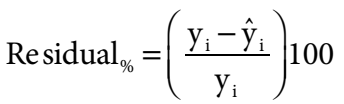

cov: covariance; $y_{i}$ observed value; $\hat{y}_{i}$ : estimated value; $\mathrm{S}$ : variance; $\bar{y}$ : mean of the observed values; $n$ : number of observations.

Once the model was selected, the model identity test (MIT) was used to evaluate whether the growth curves differed between stands in the different sites. This procedure tests whether the parameters of the equations in question are statistically different. The test, described by Graybill (1976), is based on the application of the F test on the statistic given by the ratio between the mean square of the difference (between the full model and the reduced one) and the mean square of the complete model.

The complete model was obtained by fitting an equation for each site to be compared. Thus, its mean square was computed, by the sum of the residual sum of squares of these equations divided by their total number of parameters. The reduced model consisted of fitting a single equation for the data combining sites. Thus, the mean square of the difference is obtained by the difference between the sum of squares of the complete model and the reduced one divided by the difference between the number of parameters in the complete and reduced models.

First, a general MIT was performed to test whether at least one of the stands had a different growth from the others. Then, the locations were compared two by two. For the comparison to be compatible among stands of different ages, data for stands older than the current youngest stand were removed. For example, to compare Figueirópolis (6 years) and Indiavaí (33 years), the data over 6 years of Indiavaí were discarded, 
a new fitting was performed, and the comparison was made. The level of significance was 5\%. All model fitting and statistical procedures were implemented in the $\mathrm{R}$ programming language ( $\mathrm{R}$ Core Team, 2015).

\section{RESULTS AND DISCUSSION}

All the coefficients of the models fitted for every site were statistically significant at $95 \%$ probability, except for the parameter $\beta_{1}$ of the Chapman-Richards equation in the Figueirópolis stand. All of the fittings resulted in correlation coefficients $\left(r_{\hat{y y y}}\right)$ above 0.91 (Table 3 ).

The equations presented errors below 10\% (RMSE), except for the stand in the municipality of Santo Antônio do Leverger. Low values of mean error of the estimates are desirable in regression models, since they indicate that the functional relationship $[\mathrm{DH}=\mathrm{f}(\mathrm{Age})]$ adequately described the variation of the dominant heights with the age of the trees, as also verified by Bermejo et al. (2004); Chaves et al. (2016) and Drescher et al. (2016) for teak stands.
The four tested models resulted in equations with very similar fitting statistics in each site with variations less than $1 \%$ for $r_{\mathrm{yy}}$ and RMSE\%. Thus, it was possible to infer that growth in dominant height for these teak stands can be estimated using any of the four fitted equations.

In the graphical analysis (Figure 2), it can be observed in general that the residues were distributed homogeneously from the age of 5 onwards. However, below this age, overestimation and underestimation trends were identified. This type of instability in the early growth phase is typical in teak height growth modeling, which has been also reported in other studies (e.g. Chaves et al., 2016; Figueiredo, 2005). Chaves et al. (2016) report that this phenomenon occurs because the plants are in an adaptation period, which is the phase when there is the greatest heterogeneity in the stand. This explains, in part, that when assessing the local productive capacity by means of the dominant height, databases of stands at very young ages should not be used as a reference (Machado et al., 1997).

Table 3. Coefficients and statistics of the adjustments for the equations of dominant height.

\begin{tabular}{|c|c|c|c|c|c|c|}
\hline Site & Model & $\hat{\beta}_{0}$ & $\hat{\beta}_{1}$ & $\hat{\beta}_{2}$ & $\mathbf{r}_{\mathbf{y} \hat{y}}$ & RMSE $\%$ \\
\hline \multirow{4}{*}{ Cáceres } & Gompertz & $19.8223^{*}$ & $0.4609^{*}$ & $0.2074^{*}$ & 0.956 & 7.814 \\
\hline & Chapman-Richards & $21.8176^{*}$ & $0.1069^{*}$ & $0.7252^{*}$ & 0.960 & 7.496 \\
\hline & Weibull & $22.6766^{*}$ & $0.1973^{*}$ & $0.7954^{*}$ & 0.960 & 7.472 \\
\hline & Schumacher & $3.0945^{*}$ & $-2.9954^{*}$ & - & 0.951 & 8.254 \\
\hline \multirow{4}{*}{ Indiavaí } & Gompertz & $24.3423^{*}$ & $0.4358^{*}$ & $0.1514^{*}$ & 0.964 & 6.845 \\
\hline & Chapman-Richards & $25.6305^{*}$ & $0.0871^{*}$ & $0.7167^{*}$ & 0.973 & 5.953 \\
\hline & Weibull & $26.2693^{*}$ & $0.1743^{*}$ & $0.7944^{*}$ & 0.974 & 5.854 \\
\hline & Schumacher & $3.2981^{*}$ & $-2.8951^{*}$ & - & 0.972 & 6.130 \\
\hline \multirow{4}{*}{$\begin{array}{c}\text { Figueirópolis } \\
\text { D’Oeste }\end{array}$} & Gompertz & $13.8079^{*}$ & $0.2452^{*}$ & $0.3490^{*}$ & 0.945 & 5.593 \\
\hline & Chapman-Richards & $16.5832^{*}$ & $0.1321^{\mathrm{ns}}$ & $0.5622^{*}$ & 0.946 & 5.595 \\
\hline & Weibull & $18.5028^{*}$ & $0.3205^{*}$ & $0.6449^{*}$ & 0.946 & 5.591 \\
\hline & Schumacher & $2.6964^{*}$ & $-1.4768^{*}$ & - & 0.940 & 5.868 \\
\hline \multirow{4}{*}{$\begin{array}{l}\text { Nova } \\
\text { Maringá }\end{array}$} & Gompertz & $20.2083^{*}$ & $0.4535^{*}$ & $0.2979^{*}$ & 0.957 & 6.484 \\
\hline & Chapman-Richards & $20.8060^{*}$ & $0.2057^{*}$ & $0.8515^{*}$ & 0.960 & 6.248 \\
\hline & Weibull & $21.1016^{*}$ & $0.2683^{*}$ & $0.8981^{*}$ & 0.960 & 6.229 \\
\hline & Schumacher & $3.1429^{*}$ & $-2.2819^{*}$ & - & 0.960 & 6.228 \\
\hline \multirow{4}{*}{$\begin{array}{c}\text { Santo Antônio do } \\
\text { Leverger }\end{array}$} & Gompertz & $11.8947^{*}$ & $0.9581^{*}$ & $0.4814^{*}$ & 0.912 & 11.960 \\
\hline & Chapman-Richards & $12.2575^{*}$ & $0.3869^{*}$ & $1.6666^{*}$ & 0.912 & 11.945 \\
\hline & Weibull & $12.0153^{*}$ & $0.1813^{*}$ & $1.3318^{*}$ & 0.912 & 11.945 \\
\hline & Schumacher & $2.7518^{*}$ & $-2.5664^{*}$ & - & 0.911 & 11.978 \\
\hline
\end{tabular}


Table 3. Continued...

\begin{tabular}{ccccccc}
\multirow{2}{*}{ Site } & Model & $\hat{\beta}_{0}$ & $\hat{\beta}_{1}$ & $\hat{\beta}_{2}$ & $\mathbf{r}_{y \hat{y}}$ & RMSE\% \\
\cline { 3 - 7 } & Gompertz & $17.0653^{*}$ & $0.8850^{*}$ & $0.4258^{*}$ & 0.941 & 9.636 \\
\multirow{2}{*}{ Alta Floresta } & Chapman-Richards & $17.5576^{*}$ & $0.3277^{*}$ & $1.4741^{*}$ & 0.941 & 9.587 \\
& Weibull & $17.3043^{*}$ & $0.1807^{*}$ & $1.2429^{*}$ & 0.941 & 9.584 \\
& Schumacher & $3.0819^{*}$ & $-2.6636^{*}$ & - & 0.941 & 9.596 \\
\hline
\end{tabular}

$\beta$ : estimated regression coefficients; $r_{y \hat{y}}$ : correlation coefficient; RMSE\%: root mean square error.
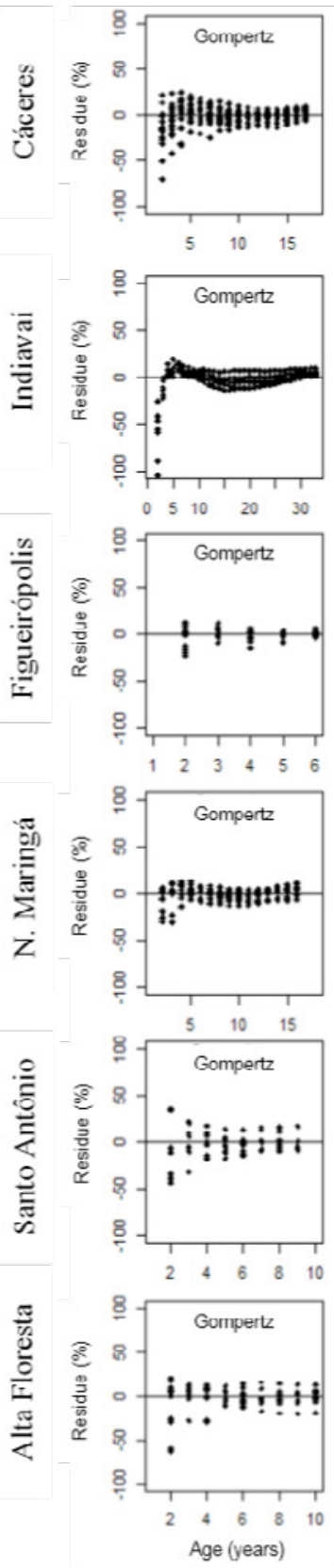
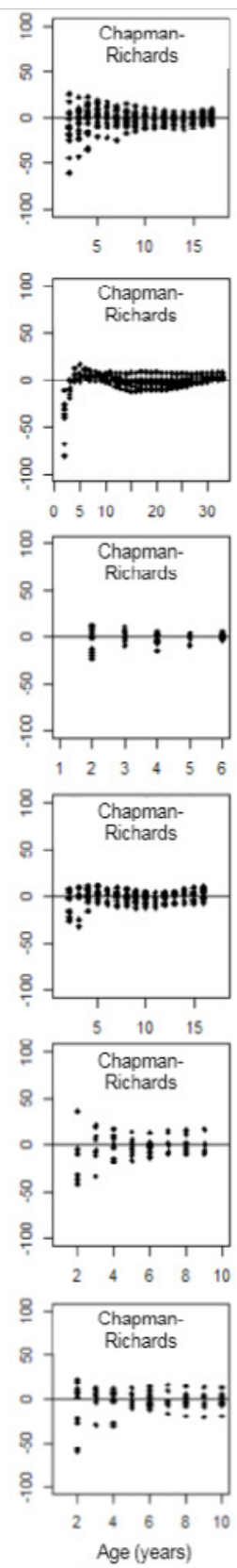
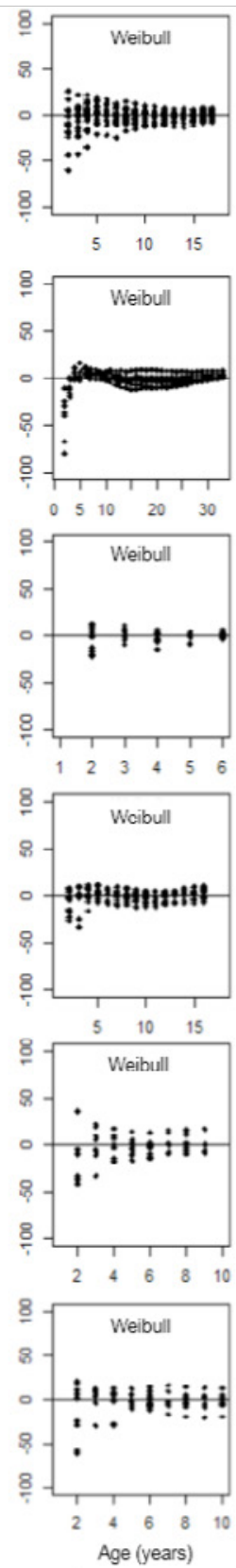
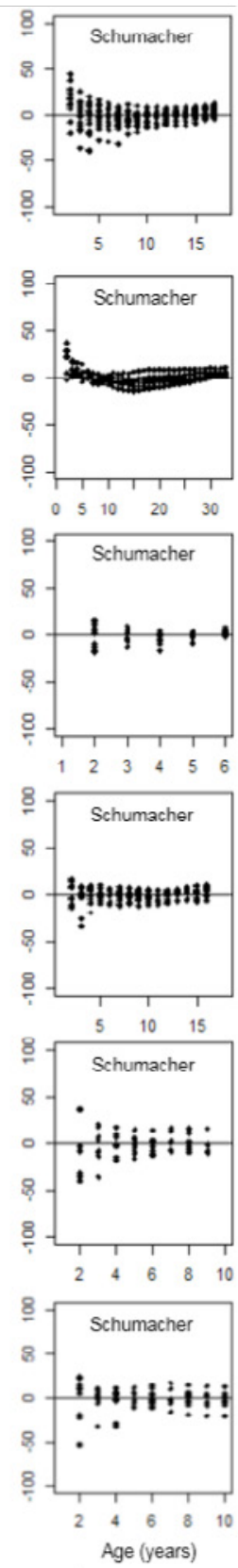

Figure 2. Residual dispersion for the tested growth models. 
Among the equations, Weibull's had a slight superiority, since a better stability and/or tendency in the distribution of its residues was verified. Therefore, this equation was used to model the stand growth in the studied localities.

The graph in Figure 3 displays the dominant height growth curves estimated by the Weibull equation for the six stands. The age of 10 was established as the reference, according to Drescher et al. (2016), and the curves of the younger stands extrapolated (dashed lines) this age for better comparison. Nonlinearity in the dominant height growth trends was observed in the different teak stands under examination, thereby confirming the suitability of the tested non-linear models.

By analyzing the growth curves at dominant height, the particularities concerning the growth trends of stands in the different localities was observed. We could see a rapid growth in the early ages and, as the stands aged, depending on the site, the growth tended to slow down, especially in the stands of Alta Floresta, Nova Maringá, and Santo Antônio do Leverger. These stands presented, although little expressively, a deceleration in growth close to the age of 8 . According to Camino \& Morales (2013), the general trend found in teak stands is rapid initial growth (up to the 5 th year), followed by moderate growth and tending to stabilize at more advanced ages.
The stand in Santo Antônio do Leverger showed the lowest growth, which can be an effect of site factors associated with competition due to the high density of trees $(1,667$ trees/ha) until the age of 9 without thinning. Medeiros et al. (2017) mentioned that, in dense teak stands, the technical age of thinning occurs around the age of 6 . However, in the teak stands present in Caceres, the above trend was not observed, although the teak stands in Caceres were unthinned and older than the stand in Santo Antônio do Leverger. In the Cáceres (unthinned stand) and Indiavaí (thinned stand) regions, the dominant height had an increasing trend, denoting an adequate site productive potential. Thus, it explains the concentration of most of the teak plantations in these regions of MT (Famato, 2013).

Considering the growth up to the reference age (10 years), the best development in dominant height was observed in Nova Maringá. This is certainly the effect of the fertilization carried out in the first two years, associated with favorable site characteristics and the adoption of silvicultural techniques such as pruning and thinning, which are indispensable for the success of commercial teak stands (Pelissari et al., 2013).

The model identity test for all grouped stands indicated that at least one site differed from the others, rejecting the null hypothesis $(p$-value $<0.01)$.

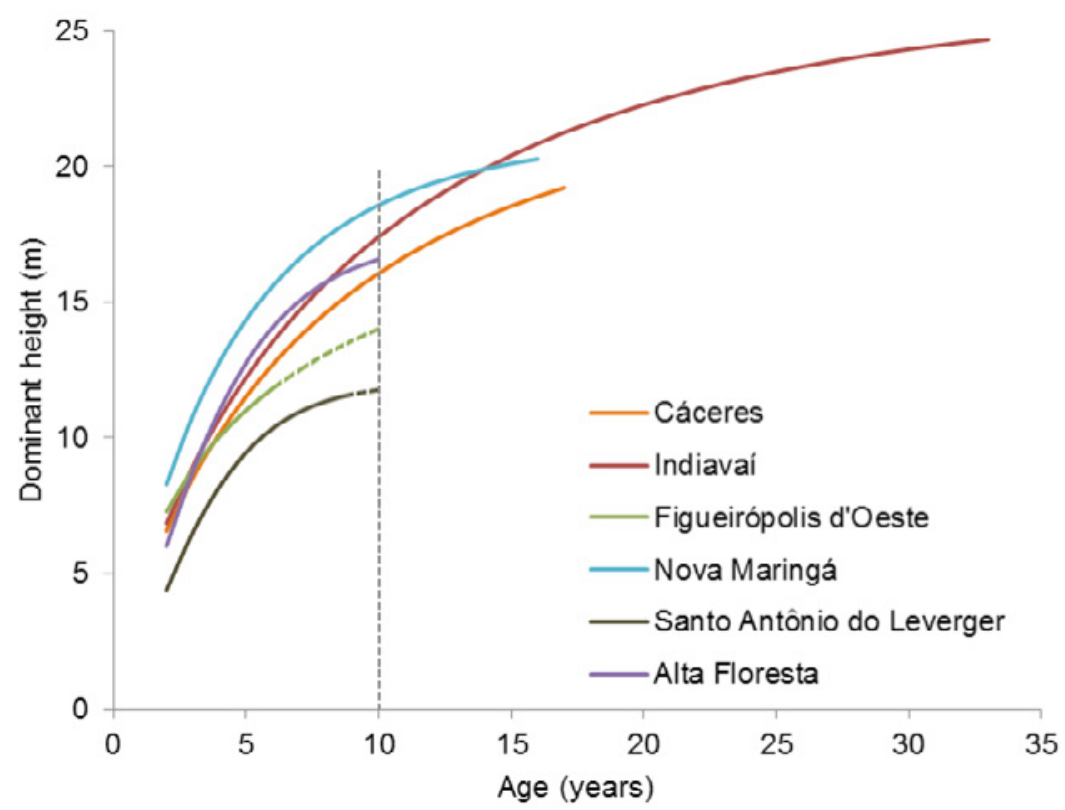

Figure 3. Growth in dominant height of Tectona grandis estimated by the Weibull equation in six municipalities in the state of Mato Grosso, mid-west Brazil. 
The pair-wise tests also resulted in significance in all comparisons, denoting that a single equation cannot be used to describe the dominant height growth of stands in the studied regions (Table 4). These results corroborate Medeiros et al. (2018), which highlighted a sizeable variation in growth and productivity of Tectona grandis stands in MT.

The studies also revealed that sites Nova Maringá and Santo Antônio do Leverger exhibited the highest and lowest development in the growth of dominant height at the age of 10 , respectively, thereby showing the maximum difference in growth, that is, $37 \%$. Except the stands located in Santo Antônio do Leverger and Figueirópolis d'Oeste, all the other stands presented higher dominant height growth than that recorded in the state of Pará (Conceição et al., 2012). For the stand in Indiavaí (oldest one) the average growth curve reached values of approximately $22.7 \%$ (24.6 $\mathrm{m}$ at age 33 ) higher than the teak growth studies carried out in Bangladesh, with a dominant height of $19 \mathrm{~m}$ at the same age (Sajjaduzzaman et al., 2005). In contrast to other countries that are competitive regarding world teak production, the Indiavaí region has higher dominant height values than studies performed in India and northern Ghana (Upadhyay et al., 2005).

The results of teak growth in MT indicate that the culture of these species meets the expectations regarding growth and high productive potential in several regions of the state, corroborating the findings of Pelissari et al. (2013) in Nossa Senhora do Livramento; Drescher et al. (2016) in Santo Antônio do Leverger and Brasnorte; and Chaves et al. (2016) in Indiavaí. These researchers also highlight the superior development of teak as compared to other South American countries, as well as the countries where the species naturally occurs.
The high growth variation found between the studied sites can be attributed to soil variability, with different degrees of fertility across the state of MT. The climatic characteristics, which have a strong effect on forest growth, are similar between sites so that no considerable effect would be expected, as shown by Medeiros et al. (2018). These authors also report that, in this state, there are few soil classes that do not restrict the cultivation of teak (3\%), and that about $62 \%$ of the soils of the state are suitable but with some restrictions related to soil mean texture, depth, drainage or natural fertility. Additionally, according to Golfari et al. (1978), the climate influences the adaptation of a genotype, while the soil regulates the level of production.

Also, part of this growth difference may be related to the different silvicultural treatments applied to the stands, such as: thinned versus unthinned. For example, Ferraz Filho et al. (2018) found significant differences in the dominant height of thinned versus unthinned stands of Eucalyptus, although this is not the usual trend in forest stands.

In addition, an alternative to quantify the productive potential is by using the site index through site curves, which are usually employed to support the choice of teak sites (Chaves et al., 2016; Drescher et al., 2016; Silva et al., 2015; Ziech et al., 2016). The advantage of this technique is that different productivity classes can be generated for the same region.

Indeed, the choice of sites for the cultivation of teak in MT is a vital decision for the growing number of investors that bet on this culture. Since there is a considerable variation across this state, different responses between the genetic materials may occur because of genotype-environment of the interactions. However, with information on the productive potential of different sites, new investments can be based on the

Table 4. $P$-values for the model identity tests applied to the Weibull growth model.

\begin{tabular}{cccccc} 
Sites & B & C & D & E & F \\
A & $3.15 \times 10^{-29^{*}}$ & $3.89 \times 10^{-05^{*}}$ & $1.02 \times 10^{-59^{*}}$ & $1.18 \times 10^{-31^{*}}$ & $1.20 \times 10^{-05^{*}}$ \\
B & & $9.76 \times 10^{-23^{*}}$ & $5.32 \times 10^{-20^{*}}$ & $2.25 \times 10^{-42^{*}}$ & $1.78 \times 10^{-03^{*}}$ \\
C & & $2.86 \times 10^{-33^{*}}$ & $1.39 \times 10^{-20^{*}}$ & $2.18 \times 10^{-12^{*}}$ \\
D & & & $5.43 \times 10^{-62^{*}}$ & $7.26 \times 10^{-19^{*}}$ \\
E & & & & $7.82 \times 10^{-38^{*}}$ \\
\hline
\end{tabular}

A: Cáceres; B: Indiavaí; C: Figueirópolis d’Oeste; D: Nova Maringá; E: Santo Antônio do Leverger; F: Alta Floresta; *: significant at 5\% probability. 
regions with the highest productive potential, such as sites with more favorable climatic and edaphic conditions to the cultivation of teak.

\section{CONCLUSIONS}

The dominant height growth trends varied between the studied sites in different regions of the state of Mato Grosso, mid-west Brazil. These differences reached up to $37 \%$ in dominant height.

\section{ACKNOWLEDGEMENTS}

The authors are thankful to the Federal Institute of Education, Science and Technology from Mato Grosso, Olegário Baldo campus, for the support in collecting part of the data.

\section{SUBMISSION STATUS}

Received: 14 June, 2017

Accepted: 31 July, 2018

\section{CORRESPONDENCE TO}

\section{Diogo Guido Streck Vendruscolo}

Proterra - Projetos, Agrimensura \& Ambiental, Av. Moises Dorneles Montiel, 1.376, Centro, CEP 78665-000, Alto Boa Vista, MT, Brazil e-mail:diogoguido@hotmail.com

\section{FINANCIAL SUPPORT}

Coordenação de Aperfeiçoamento de Pessoal de Nível Superior (Capes).

\section{REFERENCES}

Assmann E. The principles of forest yield study: studies in the organic production, structure, increment and yield of forest stands. New York: Pergamon Press; 1970.

Bermejo I, Cañellas I, San Miguel A. Growth and yield models for teak plantations in Costa Rica. Forest Ecology and Management 2004; 189: 97-110. 10.1016/j. foreco.2003.07.031

Burkhart HE, Tomé M. Evaluating site quality. In: Burkhart HE, Tomé M. Modeling forest trees and stands. Heidelberg: Springer; 2012. p. 131-173.
Camino R, Morales JP, editors. Las plantaciones de teca en América Latina: mitos y realidades. Turrialba: Catie; 2013. Campos JCC, Leite HG. Mensuração florestal: perguntas e respostas. 3rd ed. Viçosa: Editora UFV; 2013.

Chaves AGS, Drescher R, Caldeira SF, Martinez DT, Vendruscolo DGS. Capacidade produtiva de Tectona grandis L.f no Sudoeste de Mato Grosso. Scientia Forestalis 2016; 44(104): 415-424. 10.18671/scifor.v44n110.14

Conceição FX, Drescher R, Pelissari AL, Lanssanova LR, Favalessa CMC, Roquette JG. Capacidade produtiva local de Tectona grandis em Monte Dourado, estado do Pará, Brasil. Ciência Rural 2012; 42(5): 822-827. 10.1590/ S0103-84782012005000011

Cunha Neto FV, Vendruscolo DGS, Drescher R. Artificial form factor equations for Tectona grandis in different spacings. African Journal of Agricultural Research 2016; 11(37): 3554-3561. 10.5897/ajar2016.11379

Drescher R, Nunes GM, Martinez DT, Pelissari AL. Capacidade produtiva do sítio em povoamentos jovens de Tectona grandis L. f. de duas regiões do estado de Mato Grosso - Brasil. Revista Brasileira de Biometria 2016; 34(2): 233-242.

Federação da Agricultura e Pecuária do Estado de Mato Grosso - Famato. Diagnóstico de florestas plantadas do estado de Mato Grosso. Cuiabá: Instituto Mato-Grossense de Economia Agropecuária; 2013.

Ferraz Filho AC, Mola-Yudego B, González-Olabarria JR, Scolforo JRS. Thinning regimes and initial spacing for Eucalyptus plantations in Brazil. Anais da Academia Brasileira de Ciências 2018; 90(1): 225-265. 10.1590/00013765201720150453

Figueiredo EO. Avaliação de modelos pelo método da curva média para a construção de curvas de índice de sítio para Tectona grandis L. $f$. Rio Branco: Embrapa; 2005.

Golfari L, Caser RL, Moura VPG. Zoneamento ecológico esquemático para reflorestamento no Brasil. 2nd ed. Belo Horizonte: Centro de Pesquisa Florestal da Região do Cerrado; 1978.

Graybill FA. Theory and application of linear model. Belmont: Duxbury; 1976.

Indústria Brasileira de Árvores - IBÁ. O setor brasileiro de árvores plantadas. Brasília: IBÁ; 2016.

Kollert W, Cherubini L. Teak resources and market assessment 2010. Rome: FAO; 2012.

Machado SA, Oliveira EB, Carpanezzi AA, Bartoszeck ACPS. Classificação de sítio para bracatingais na região metropolitana de Curitiba. Boletim de Pesquisa Florestal 1997; (35): 21-37.

Machado SA, Silva LCR, Figura MA, Téo SJ, Nascimento RGM. Comparison of methods for estimating heights from complete stem analysis data for Pinus taeda. Ciência Florestal 2010; 20(1): 45-56. 10.5902/198050981760 
Medeiros RA, Paiva HN, Leite HG, Salles TT, Araújo CA Jr, Dávila FS. Idade técnica do primeiro desbaste de povoamentos de teca em diferentes espaçamentos. Scientia Forestalis 2017; 45(116): 705-716. 10.18671/scifor.v45n116.11

Medeiros RA, Paiva HN, Marcatti G. Tectona grandis: zoneamento ecológico para o cultivo no estado de Mato Grosso, Brasil. Beau Bassin: Novas Edições Acadêmicas; 2018.

Pandey D, Brown C. Teak: a global overview. Unasylva 2000; 51(201): 3-13.

Pelissari AL, Caldeira SF, Drescher R. Desenvolvimento quantitativo e qualitativo de Tectona grandis L.f. em Mato Grosso. Floresta e Ambiente 2013; 20(3): 371-383. 10.4322/ floram.2013.027

Pelissari AL, Guimarães PP, Behling A, Ebling AA. Cultivo da teca: características da espécie para implantação e condução de povoamentos florestais. Agrarian Academy 2014; 1(1): 127-145.

Priya PB, Bhat KM. False ring formation in teak (Tectona grandis L.f.) and the influence of environmental factors. Forest Ecology and Management 1998; 108: 215-222. 10.18677/Agrarian_Academy_2014_011

Prodan M, Peters R, Cox F, Real P. Mensura forestal. San Jose: IICA; 1997.

$\mathrm{R}$ Core Team. R: a language and environment for statistical computing. Vienna: R Foundation for Statistical Computing; 2015 [cited 2015]. Available from: http:// www.R-project.org
Sajjaduzzaman MD, Mollick AS, Mitlohner R, Muhammed N, Kamal MT. Site index for teak (Tectona grandis Linn. F.) in forest plantations of Bangladesh. International Journal of Agriculture \& Biology 2005; 7(4): 547-549.

Shimizu JY, Klein H, Oliveira JRV. Diagnóstico das plantações florestais em Mato Grosso. Cuiabá: Central de Texto; 2007.

Silva FR, Moraes e Silva VS, Miranda SO, Gava FH, Drescher R. Aplicação do modelo de Schumacher para expressar a capacidade produtiva em um plantio jovem de Tectona grandis. Advances in Forestry Science 2015; 2(4): 79-84. 10.34062/afs.v2i4.2907

Upadhyay A, Eid T, Sankhayan PL. Construction of site index equations for even aged stands of Tectona grandis (teak) from permanent plot data in India. Forest Ecology and Management 2005; 212(1-3): 14-22. 10.1016/j. foreco.2005.02.058

Vallejos Barra OS. Productividad y relaciones del índice de sitio con variables fisiográficas, edafoclimáticas y foliares para Tectona grandis L.F., Bombacopsis quinatum (Jacq.) Dugand y Gmelina arborea Roxb. en Costa Rica [thesis]. Turrialba: Centro Agronómico Tropical de Investigación; 1996.

Van Laar A, Akça A. Forest mensuration. Berlin: Springer Science+Business Media; 2007.

Ziech BG, Moraes e Silva VS, Drescher R, Vendruscolo DGS. Modelos de crescimento em altura dominante e índice de sítio para teca em Glória D’Oeste-MT. Revista Brasileira de Biometria 2016; 34(4): 533-542. 